\title{
臨床心理学における科学性規準の変遷
}

\section{保田 直美}

\section{1. 覧床心理士の学校への職域拡大}

近年，いじめや不登校が問題化する中，学校において「心の専門家」が一定の職 務を担うことが多く見られるようになっている。なかでも, 現在学校において独自 の職域を確保しつつあるのが, 日本臨床心理士資格認定協会の認定する臨床心理士 である(1)。臨床心理士は, 主にスクールカウンセラー制度を通してその職域の確保を 進めており, 文部科学省初等中等教育局児童生徒課によると, 平成13年度に中学校 に派遣されたスクールカウンセラー2,083名(2)のうち，1,599名（約77\%）が臨床心 理士の有資格者となっている。

このような学校への臨床心理士の職域拡大は, 社会全体の心理主義化傾向の 1 つ の具現化として捉えることが一般的である。例えば，森（1999）は「さまざまな制 度や日常生活において, 心理学的知識やパースペクティブを受容し, その知識を基 準に行為を選択する人々が增加している」社会的傾向を指して,「心理主義化」と呼 び(37頁), このような社会の心理主義化は, 人格崇拝が高度化し合理化が進行した 現代社会において, 高度な自己コントロールが要求されている状況を反映している とした。教育社会学においても，このような「心」を重視する見方の拡大を，教育 言説の時系列的な展開の中に検証する研究が進められている（伊藤 1996 , 加野 2001)。

しかし, 心理主義化の結果として, あらゆるフィールドで臨床心理士の職域が拡 大しているかというとそうではない。例えば, 病院における臨床心理士の職域の確

大阪大学大学院 
保および身分的な保証は難航している。病院はもともと臨床心理士にとって主要な 職場であり, 臨床心理士は, 独自の職域を病院内に確保し制度化することを長年望 んできた。しかし，この要望に対する厚生労働省の対応は芳しくなく, 現在, 厚生 労働省において進められつつある心理臨床的職業資格（医療保健心理士）の検討て は, 臨床心理学が医学から独立した専門職の学問的基盤であるとは認められていな い。つまり, その活動はあくまでも医師の指示のもとで, 医学を基盤として行うこ ととされているのである（鈴木 2002，日本臨床心理士会 2002）。

また，学校における職域拡大も，これまで決して順調に進んできたわけではない。 今回の活動以前にも, 心理臨床家(3)は学校に対してアプローチを行っているが, 1970 年代以前に 2 度行われたアプローチは，いずれも臨床心理学の考え方を導入し，心 理臨床家独自の役割を学校に見いだすという意味では, 失敗に終わっている（保田 2001)。

では, なぜ, 病院で難航している臨床心理士独自の職域の獲得が, 現在, 特に学 校において, スムーズに進みつつあるのだろうか。また, なぜ, 学校においても, 過去にはうまくいかなかったにもかかわらず，今回成功しているのだろうか。本稿 は, その背景が, 専門職としての臨床心理士が拠って立つ臨床心理学という学問自 体の特性の中に見いだせると考え，これを試論的に検討することを目的とする。つ まり, 近年の学校での急速な職域拡大の背景には, 臨床心理学の学問自体に, 学校 との親和性を強化する何らかの変化があったと予想されるのである。

\section{2. 倫理的規準としての教科書知}

専門職とは, 広義に捉えるなら, 問題解決能力を有している職業であり(4), その意 味では, 臨床心理士などの心理臨床家も一種の専門職といえる。専門職の実践は, ある問題に対する診断と処置とそれらの間をつなぐ推論という 3 つの側面で表すこ とができる(Abbott 1988)。つまり, 専門職の職務は, 診断と処置とその間をつな ぐ推論を行うためのフォーマライズされた知の体系に基礎づけられているのである。 そのため, 職域の拡大を考える際には，その専門職としての活動を基礎づける知的 な背景を考慮することが重要になってくる。専門職の知の体系は，実際に問題解決 に役立つという実利的な側面と, 役立つと人々に思わせることができるという象徵 的な側面とをもっている (Torstendahl 1990)。したがって，知の体系は，社会的 地位を確立していく能力を専門職に与え, それが職域の拡大につながるのである。 ここでは, 心理臨床家を専門職として基礎づける知の体系を臨床心理学的知と呼 
臨床心理学における科学性規準の变縓

ぶ。臨床心理学的知とは, 臨床心理学的な考え方全般をさしている。それは, 専門 家集団に流通している専門知と，専門家集団の手を離れ，一般に流通している民間 知の双方を含むものであり，また，単に明文化された形式知だけでなく，それを学 ぶ者・知る者が身に付けている態度などの暗黙知も含むものとする。本稿は, 大き くはこの, 専門職としての職域拡大を下支えする臨床心理学的知の変化を捉えよう とするものである(5)。

しかし，ただ臨床心理学的知を捉えるというのでは，その対象範囲が非常に広く なってしまう。そのため,ここでは焦点を絞る必要がある。本稿の課題である臨床 心理士の職域拡大を考察する上で, 特に重要なのは, 臨床心理士が専門職として活 動を行う際のディシプリンに関する倫理的規準である。集団レベルで見た場合, 臨 床心理士の全体としての活動は, 何を臨床心理学とし何を臨床心理学でないとすべ きかという倫理的規準にある程度制約される。よってここでは，臨床心理学のディ シプリンに関わる心理臨床家自身の倫理的規準に焦点を絞って知の変化を検討する。 倫理的規準の変化を追うためには, 臨床心理学の教科書に記述されている知一 教科書知一一変遷を追うことが最も有効な手段であると考えられる。教科書知は, 専門知の中でも形式知を代表するものであり，フォーマルな場で学ばれるアカデミ ックな知の中心を占めるもので,従うべき行為の倫理的規準の指標となる。Kuhn(訳 書 1971）によれば，教科書とは「一連の定説を説明し，その応用を示し，さらに その適用例と観察・実験とを比較する」ものであり, それは「その研究分野の正当 な問題と方法を定める役割」を担う (12頁)。そして，そのような共通の所信を前提 として, 専門的な研究が進められていく。つまり, 教科書は専門的知識の生産の出 発点となるパラダイムなのである(6)。

また, 心理臨床家という専門職集団にとって, 教科書知は特別な意味をもつこと がSvensson（1990) によって示されている。Svensson（1990）は，専門職が実際の 活動の場において, 教科書やその他様々な形態の知をどのように用いているかを， 建築家と心理臨床家を対比しながら明らかにしている。その中で, 特に心理臨床家 に関して, 教科書に代表されるような理論的知識は, 実際の問題解決という機能以 外に, 心理臨床家の専門職集団としての疑集性を高めるという象徵的な機能をもつ ていると示唆している（59頁）。心理臨床家は，建築家と比べた場合，法律・経済・ 技術などのルールより倫理的なルールを，実践においてより多く参照する。そのた め, 心理臨床家は, 専門職としてのまとまりとそこで維持されている倫理性を強調 し, 教科書などの理論的知識——共通のことばや参照枠組み——を重んじる。ゆえ 
に，教科書の内容は，心理臨床家（臨床心理士）の倫理的規準として特に重要な意 味をもつのである。

そこで, 本稿では, 臨床心理学のディシプリンに関わる倫理的規準の変遷を追う 材料として, その教科書を用いることとする。なかでも，ディシプリンの基盤とも いえる臨床心理学の科学性を, 心理臨床家がどのように考えているかという点に注 目して，教科書の内容分析を行う。ここでいう科学性についての考え方とは，より 具体的には，臨床心理士がクライエント（対象者）にアプローチする際にもつべき 客観性あるいは主観性についての考え方のことである。特に，主観／客観の問題に 注目するのは, 一般に, 客観性が科学のエートスの根本を成すとされるからである (Merton 訳書 1961)。

また，この主観／客観の問題は，心理臨床家自身にも倫理的基準を示すものとし て重要視されている。実際, 心理臨床家が, 臨床心理学の科学性について議論する とき, 議論の中心は主観／客観の問題にある。臨床心理学においては, 臨床心理学 が科学か否かということがしばしば問題になる。一般に, 科学においては研究対象 に客観的にアプローチすることが期待されている。しかし, 臨床心理学は, クライ エントの経験の客観的事実ではなく，主観的経験（心的事実）を対象とする。さら にクライエントの主観を理解するにあたり，客観的な観察だけでは限界があるので はないかという危惧も一部の心理臨床家の間には存在する。そこには必然的に, 主 観的な見方と客観的な見方との間の葛藤が生じる。そのため，心理臨床家にとって， 科学性の問題すなわち主観と客観の問題は避けて通ることができないのである。

\section{3. 教科書の内容分析の方法}

本稿では，Krippendorff（訳書 1989）が示している計量的な内容分析の方法に 依拠しながら，分析を行っている。具体的な分析の手順は以下のとおりである。

まず，1945年から2000年までに日本で出版された臨床心理学の教科書をできるだ け多く把握することに努めた。「臨床心理学」あるいは「心理臨床」が夕イトルに含 まれる概論的内容のものを教科書と考え，検索・現物確認などを行った結果，単行 本 53 冊・複数巻組 6 シリーズ 38 冊の計 91 冊を把握することができた。把握した全教 科書のタイトル等の情報は付表 1 （136頁）に記載している。以下，分析結果を示す 際に用いる文献番号はすべて，この付表 1 の文献番号に対応している。

教科書知の変遷を捉えるためには，これらの教科書のうち影響力の強かったもの を重点的に調べなければならない。そこで, 国立情報学研究所の Webcat の文献所 
蔵検索により出力される所蔵図書館件数（2000年10月時点）を重要度の指標とした。 分析対象としたのは，全教科書のうち各年代（1950年代・1960年代・1970年代・1980 年代・1990年代・2000年代）の所蔵館件数上位 3 シリーズずつ, 計 16 シリーズ 45 冊 である(7)。

事前にいくつかの教科書を通読したところ, 科学性についての考え方を抽出でき る個所は, 臨床心理学の定義やあるべき姿などについて記述している章・節に限ら れることが確認された。そこで, 分析対象の 45 冊の中から, 臨床心理学の定義やあ るべき姿などについて記述していると思われる章・節を, 実際の分析対象を抜き出 すためのサンプリング単位として抜き出した。各教科書から抜き出された章・節は, 付表 2 (137頁) のとおりである。この表での章・節記号は, 分析結果を示す際にも 用いている。

実際の分析作業としては，これらの章・節（サンプリング単位）を通読し，その 中から「科学」「主観／客観」「主体」というキーワードに関して記述している個所 を記録単位として抜き書きし，それぞれ科学性に対してどのような考え方を示して いるかというコンテキストを分類して整理した。

\section{4. 臨床心理学の教科畫知の変遈}

\section{1. 科学性に対する考え方の分類}

サンプリング単位から取り出したそれぞれの記録単位の記述内容を通読し, その 文脈を比較検討した結果，以下のような分類を行うことが有効であると考えられた。 まず，科学性に対する考え方について，客観性と主観性のどちらを重視するかに注 目し, それにより客観性を重視する立場, 主観性を重視する立場, 両者ともに重視 する立場の 3 つを区別する。さらに両者とも重視する立場については, 必然的に生 じると予想される主観と客観の間の葛藤をどのように解決するかという方法によっ て分類すると, より変遷が捉えやすいと考えられた。そこで, 最後の立場について は, 主観と客観を分離させて考える解決法をとる立場と, 主観と客観を同時的に成 立させる解決法をとる立場にさらに分類した。

それぞれの分類の特徴を図で示したものが図 1 (138頁) である。では，これらの 図を参照しながら, 各分類の内容の説明を簡単に行う。なお, 結果を提示する上で の便宜上, カテゴリの説明 (4.1.節) および変遷の概要の把握（4.2.節）を先に行 い, それぞれのカテゴリに含まれる記述の具体例は, 最後にまとめて挙げることと する $(4.3$.節)。 
付衰 1 戦後日本の韵床心理学の教科害

\begin{tabular}{|c|c|c|c|}
\hline $\begin{array}{l}\text { 文献 } \\
\text { 番号*1 } \\
\end{array}$ & 発行年 & 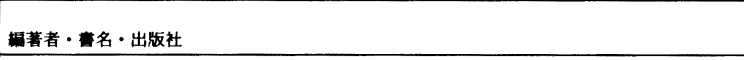 & 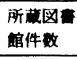 \\
\hline T01 & $1951-52$ & 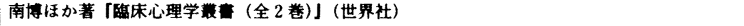 & 40 \\
\hline () $\mathrm{T} 02$ & 1952 & 戸川行男城 「臨床心理学」（金子豐房） & 109 \\
\hline T03 & 1954 & 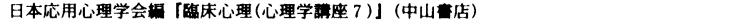 & 47 \\
\hline (2) T04 & 1956 & 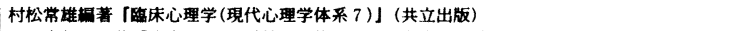 & 88 \\
\hline (O) T05 & 1958 & 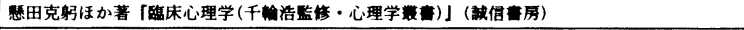 & 93 \\
\hline () T06 & 1964 & 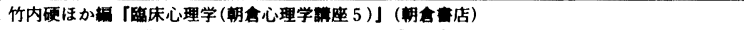 & 104 \\
\hline () $\mathrm{T} 07$ & 1966 訳 & J.B.ロッター著「程床心理学（現代心理学入門）[初版]」（岩波曹店） & 174 \\
\hline T08 & 1967 & 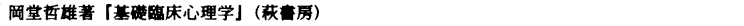 & 10 \\
\hline T09 & 1967 & 本明宽絧 〔心理学臨床入門」（福村出版） & 52 \\
\hline (c) T10 & $1968^{-}$ & 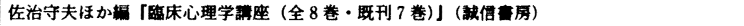 & 97 \\
\hline T11 & 1969 & 蛭川栄ほか著「臨床心理学：技法とその背景」(明售房) & 36 \\
\hline $\mathrm{T} 12$ & 1971 & 戸川行男著「臨床心理学論考」(金子害房) & 90 \\
\hline (9) $\mathrm{T} 13$ & 1972 & 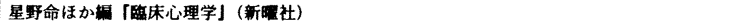 & 106 \\
\hline T14 & 1972 & 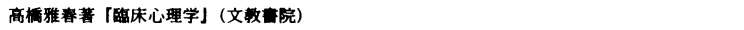 & 17 \\
\hline T15 & 1974 & 氏原宽著「酶床心理学入門：カウンセラーを志す人のために」（籼元社） & 62 \\
\hline T16 & 1974 & 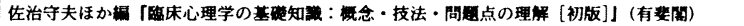 & 81 \\
\hline $\mathrm{T} 17$ & 1975 & 村田正次ほか著「臨床心理学：子どものよりよい理鲜者となるために」(既林館) & 6 \\
\hline T18 & 1977 & 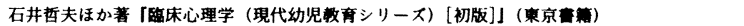 & 27 \\
\hline $\mathrm{T} 19$ & 1977 & 石井暂夫ほか著「覧床心理学 （現代幼児教育シリース）[第 2 版]]（東京䡒籍） & 15 \\
\hline $\mathrm{T} 20$ & 1978 & 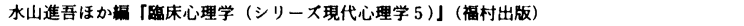 & 57 \\
\hline (O) $\mathrm{T} 21$ & 1979 & 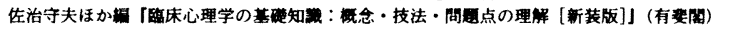 & 124 \\
\hline (O) $\mathrm{T} 22$ & 1979 & 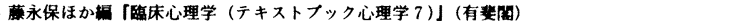 & 103 \\
\hline $\mathrm{T} 23$ & 1979 & 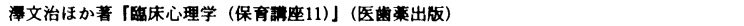 & 37 \\
\hline $\mathrm{T} 24$ & 1979 & 岡堂哲雄楄 [心理監床入門［初版]」（新樶社） & 58 \\
\hline () $\mathrm{T} 25$ & 1980 訳 & S.J.コーチン著「現代臨床心理学：クリニックとコミュニティにおける介入の原理」(弘文堂) & 140 \\
\hline $\mathrm{T} 26$ & 1980 & 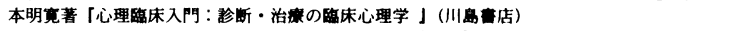 & 74 \\
\hline T27 & 1980 & 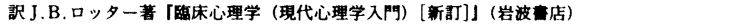 & 115 \\
\hline $\mathrm{T} 28$ & 1981 & 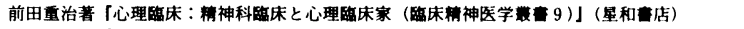 & 59 \\
\hline $\mathrm{T} 29$ & 1981 & 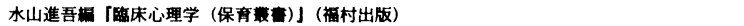 & 28 \\
\hline T30 & 1983 & 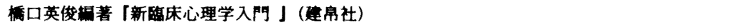 & 48 \\
\hline (a) $\mathrm{T} 31$ & 1986 & 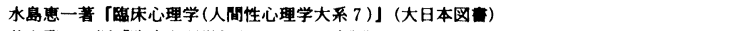 & 147 \\
\hline $\mathrm{T} 32$ & 1986 & 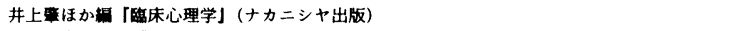 & 49 \\
\hline T33 & 1986 & 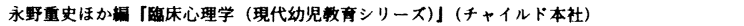 & 16 \\
\hline $\mathrm{T} 34$ & 1987 & 村瀨孝雄萻「臨床心理学（放送大学教材）[初版]」(放送大学教育振興会) & 54 \\
\hline T35 & 1987 & 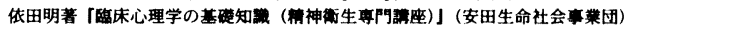 & 32 \\
\hline T36 & 1988 & 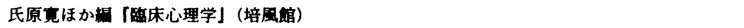 & 91 \\
\hline T37 & 1988 & 田中富士夫著「臨床心理学概説」(北樹出版） & 50 \\
\hline $\mathrm{T} 38$ & 1988 & 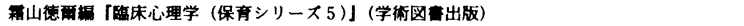 & 13 \\
\hline T39 & $1988-91$ & 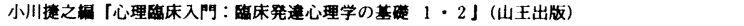 & 70 \\
\hline T40 & 1989 & 岡堂哲雄閖「臨床心理学 [初版]」(日本文化科学社) & 56 \\
\hline (2) $\mathrm{T} 41$ & 1989- & 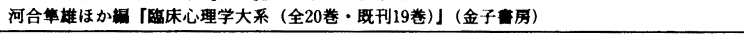 & $266 * 3$ \\
\hline T42 & 1990 & 台利夫ほか編「現代酶床心理学」(教育出版) & 65 \\
\hline $\mathrm{T} 43$ & 1991 & 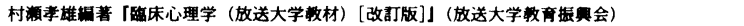 & 63 \\
\hline (C) T44 & $1991-95$ & 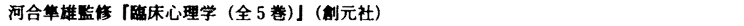 & 199 \\
\hline T45 & 1994 & 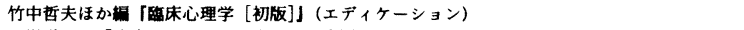 & 1 \\
\hline T46 & 1995 & 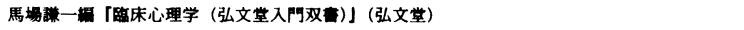 & 76 \\
\hline $\mathrm{T} 47$ & 1995 & 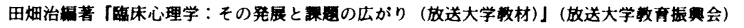 & 101 \\
\hline (c) $\mathrm{T} 48$ & 1995 & 會光传著「臨床心理学（現代心理学入門 5)」（岩波贯店） & 243 \\
\hline T49 & 1995 & 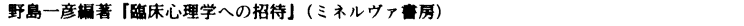 & 155 \\
\hline (O) T50 & 1996 & 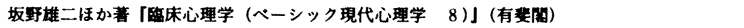 & 183 \\
\hline T51 & 1996 & 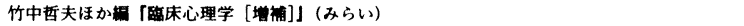 & 12 \\
\hline T52 & 1996 & 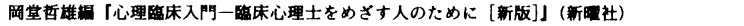 & 94 \\
\hline T53 & 1998 & 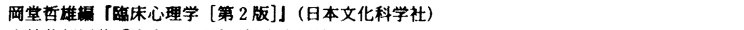 & 50 \\
\hline T54 & 1998 & 小林芳郎䦗著「臨床心理学」(保育出版社) & 9 \\
\hline T55 & 1998 & 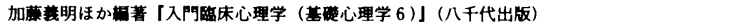 & 4 \\
\hline T56 & 1998 & 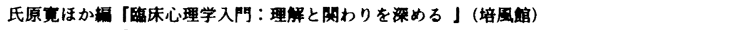 & 83 \\
\hline T57 & 1999 & 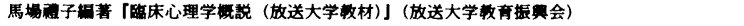 & 120 \\
\hline T58 & 1999- & 氏原宽ほか城「臨床心理学（全 3 卷)」(培風館) & 74 \\
\hline (C) $\mathrm{T} 59$ & $2000-$ & 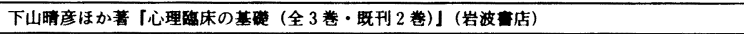 & 97 \\
\hline
\end{tabular}

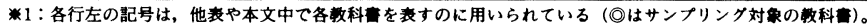

*2: 複数冊のシリースについての淁当件数は, 刊行分の平均偡 (小数点以下四拮五入)を取った。

*3：「臨床心理学大系」は全16巻て当初刊行されたが、後に追加 4 巻が決定された。当初刊行分の平均は $307 。$ 
付表 2 各数科害のサンブリング学位およびをの執筆者

\begin{tabular}{|c|c|}
\hline 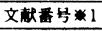 & 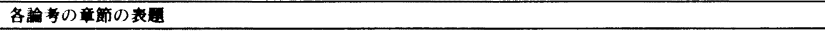 \\
\hline T02 & 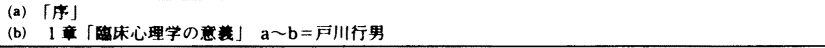 \\
\hline T04 & 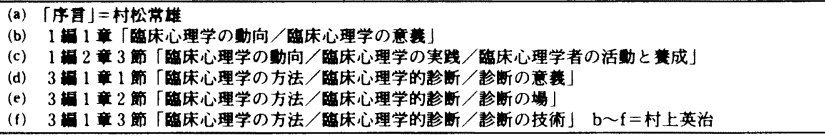 \\
\hline T05 & 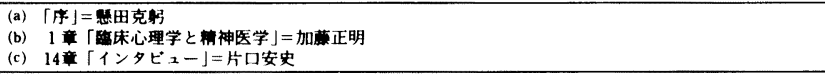 \\
\hline T06 & 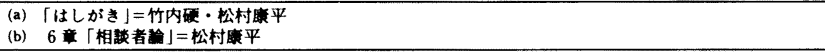 \\
\hline T07 & $\begin{array}{l}\text { (a) 「序」 } \\
\text { (b) } 1 \text { 童「臨床心理学とは何か」 } \\
\text { (c) } 6 \text { 章「臨床心理学の現状」 } \mathrm{a} \sim \mathrm{c}=\text { J.B.ロッター }\end{array}$ \\
\hline T10 & 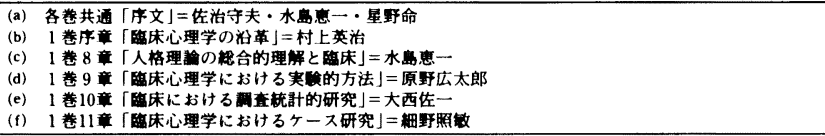 \\
\hline T13 & 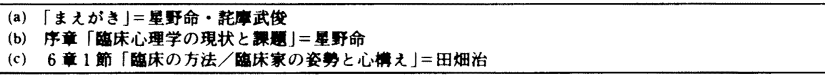 \\
\hline T21 & 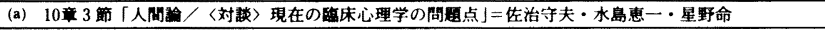 \\
\hline $\mathrm{T} 22$ & 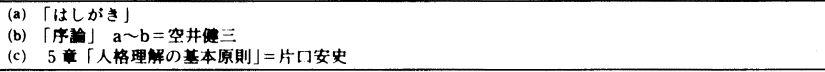 \\
\hline T25 & 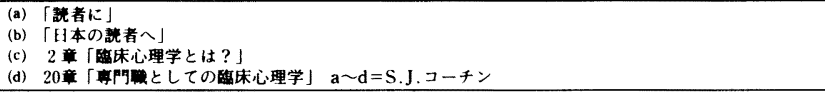 \\
\hline T31 & 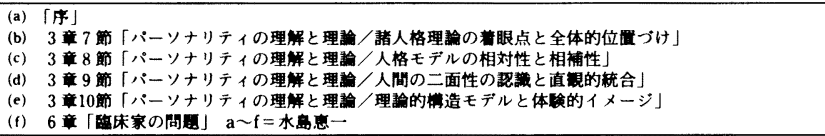 \\
\hline T41 & 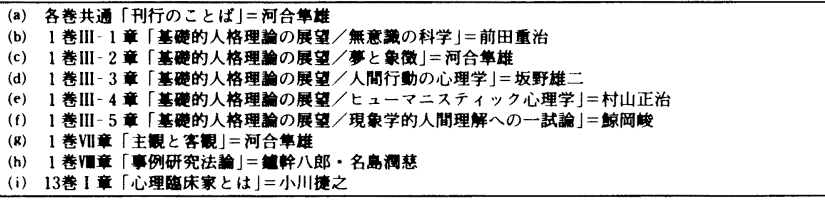 \\
\hline T44 & 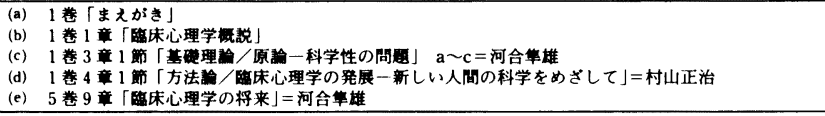 \\
\hline T48 & 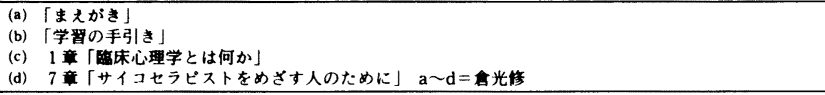 \\
\hline T50 & 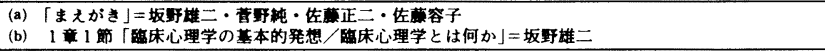 \\
\hline T59 & 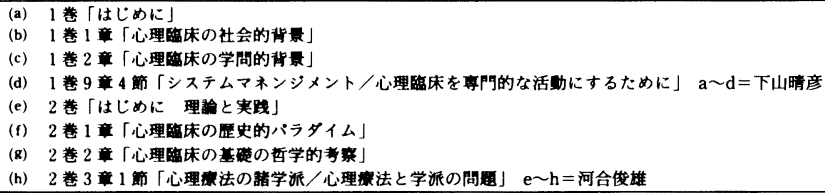 \\
\hline
\end{tabular}

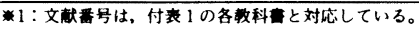




\section{A 客観臬視の立堨}

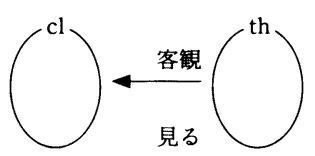

・客観的に見る

\section{B 主観亘視の立㳦}

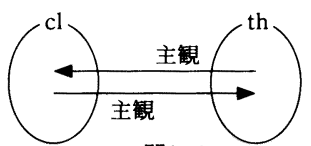

関わる

・主体的に関わる

\section{C 主客分淮型解決}

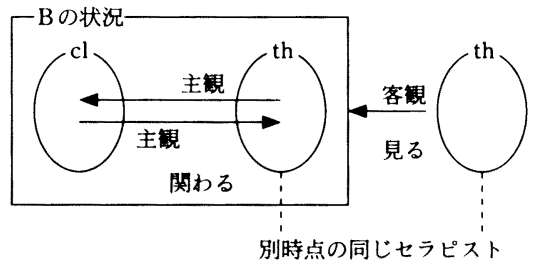

・主観と客笅が同時に成立し得ない (時間差がある)

D 主害融合型解決

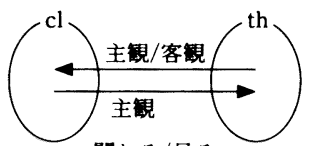

関わる/見る

\section{・主観と客襀の同時成立}

\section{E. 光の他 \\ ・ $\mathrm{A} \sim \mathrm{D}$ の分類に当てはまらないもの}

图 1 監床心理学の「科学性」に対する考元方の分斯

\section{【A 客観亚視の立場】}

客観的にクライエントを観察し，普遍的な法則に至ることを重視する立場である。 図 1 における「th」は臨床家（therapist）を表し，「cl」はクライエント (client) を 表している。客観重視の立場（A）の図は単純であり，臨床家がクライエントを一 方的に観察するのみで, クライエントが臨床家とどう関わるかは重要ではない。こ のような立場は臨床心理学の教科書において「科学」と呼ばれることが多い。

\section{【B 主観亘視の立堛】}

「人間を外側から対象化してながめたり，客体としてながめたりすることではな く, その人間自身の内面的な体験を重視し，その体験に即して共感的に理解しよう とする立場である」(村上 $1968 ， 7$ 頁 (T10-b ) )。図 1 (B) に示されているとお り，臨床家からのクライエントへの主観的な関わりが重視されているだけではなく， 
クライエントから臨床家への主観的な関わりが同時に重視されている。

主観重視の立場は, 客観重視の立場とは真っ向から対立する。しかしながら, 実 際には両者共に重視する考え方を表明している教科書も多く見られた。その葛藤は， 以下の 2 パターンで解決が示されていることが多く, それらが第 3 , 第 4 の分類で ある。

\section{【C 主客分椎型解決】}

主観と客観が同時的には成立しないとの想定のもとに，2つの立場を使い分ける ことで解決をはかる立場である。臨床家は，クライエントに向かう場面（カウンセ リング場面）では，主観重視の立場をとるが，対面場面を離れた記録，分析の場面 では，客観重視の立場をとる。図 1 （C）に示したように，主観重視（B）のカウ ンセリング場面を客観的に観察する別の視点が 1 人の臨床家によって担えると考え るのがこの立場の特徵である。主観と客観は同時的には成立しないと考える点が, $\mathrm{D}$ との相違点である。

\section{【D主害㲧合型解決】}

主観と客観が同時的に成立しうると発想を転換することで，主観と客観の暮藤を 解決する立場である。図 1 （D）に示したように，この立場の下ではクライエント に対して臨床家が主観的であると同時に客観的であることに何の問題性も見いださ ない。むしろ，主観的な関わりから客観に通じることができると想定している。そ れは, 科学の再定義であり,この立場を主張する教科書では, しばしば臨床心理学 が「新しい科学」にあたると記されている。主観と客観が同時的に成立すると考え る点が, Cとの大きな相違点である。

実際の分類作業では, 以上の分類に収まりきらないものを【E その他】とし, 5 つのカテゴリに分類した。また，同じように科学性に対する考え方を記していて も，その考え方が臨床心理学の現状を表すものとして記述されている場合もあれば, 将来的, あるいは理想的に目指すべきものとして記述されている場合もあった。こ れらのいずれであるかによって，分析上の捉え方は大きく異なるので，区別した。

\section{2. 分類の分布に見る变远の概要}

以上の分類カテゴリに従って，科学に対する考え方の分布がどのように変遷して きたのかを表した結果が表 1 (140頁) である。この表では, 分析対象となった教科 書の各章・節での記述が，まずどの分類にあたるかを，記号で記している。先述の 
表 1 臨床心理学における科学性規望の变远

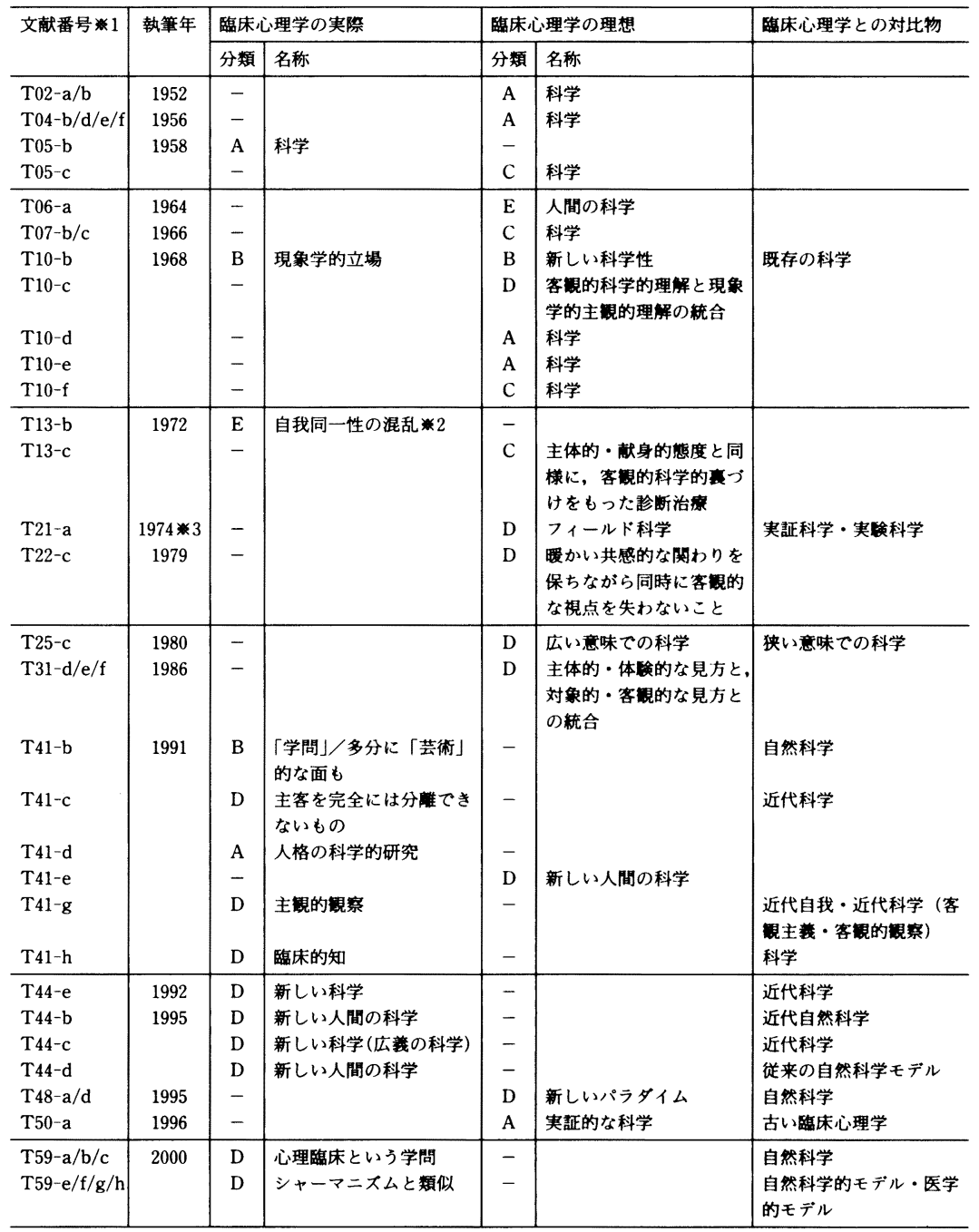

\%1：文献番号は，付表 1, 付表 2 で示されている数科害およびその童節を表している。

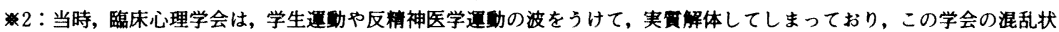
態をうけて「自我同一性の混乱」と臨床心理学の現状が銘打たれていた。

* 3：T21「臨床心理学の基礎知識：概念・技法・問題点の理解 [新装版]」の発行年は1979年だが, 初版てある T16との 間に内容の変化はないので, 執箻年は1974年としている。

分分類における「一」は，記述がなかったことを示す。なお，実際についても理想についても記述がなかったものは， 表からはあらかじめ省いている。 
とおり，実際についての記述と理想としての記述は分けて示している。また，参考 のために，記述の中でこれらの立場がどう呼ばれているかを，並置して記した。さ らに, 臨床心理学の立場と対比される考え方について記述があった場合は, これも 参考のために記しておいた。

表 1 から, 戦後の臨床心理学における科学性に対する考え方の変遷は, 大筋で次 のようにまとめられる。戦後から1970年頃まで, 臨床心理学は「科学」であること を理想とし，客観的に対象を見るという立場（A）をとることを目指す傾向が強か った。それは同時に，臨床心理学が現状として「そうではなかった」ことを示して おり，実際には主観的に関わっていかざるをえないことが多かった。そこで，脈々 と主体的に対象に関わることを重視する立場（B/C・D）は存在し，時折そのよう な立場をとる論考も出現した。1970年以前でのそのような立場の典型は, 1968年の 「臨床心理学講座」に見られる（B・D）〔T10-b/c)が, 同じ教科書内で同時に, 客 観的に対象を捉えようとする立場（A）〔T10-d/e〕や，できるだけ主観重視の立場 を「科学的」に解決しょうとする主客分離型の解決 (C)〔T10-f)も見られ，ま だ「科学」であることへの憧れが強かったことがうかがえる。

しかし，1970年に入り，教科書における記述の流れは次第に変化し始める。星野 (1972〔T13-b]) の表現によれば，1970年代初頭，科学性は「多様な社会的価值観の 広い文脈の中では, 明るい太陽の前の 1 つの星のように輝きを失っ」（5頁）てしま つた。そしてその頃から次第に, 主客融合型の解决（D）を目指す記述が増加して くる。当初は「客観的科学」という名称を残しながら，そして次第に「新しい科学」 という名称で, それは広く流通し始める。また, 主客融合型解決が理想であるとい う考えが浸透するにつれて，次第に(特に1990年代以降)，そのような主客融合型解 決（D）が，理想というより，実際として現状肯定的に記述されるようになる。臨 床心理士にとって, 臨床心理学は, 「実際」に主観と客観のパースペクティブを同時 的に用いることが可能な，つまりこれまでの「科学」を越える「新しい科学」とな つたのである。さらに，最近 (下山 $2000[\mathrm{~T} 59-\mathrm{a} / \mathrm{b} / \mathrm{c}$ ], 河合 $2000[\mathrm{~T} 59-\mathrm{e} / \mathrm{f} / \mathrm{g}$ ) h)）では,「科学」という言葉さえ, 臨床心理学を表す名称の中から消えている。も ちろんその反作用として「実証的な科学」を唱道する動き（坂野 1996 [T50-a/b]) も存在するが, 現時点での大まかな赹勢としては, 従来の「科学」への憧れはもう ないといえるだろう(8)。 


\section{3. 具体的な记述内容にみる数科貫知の变逐}

教科書知にみられるこれらの変遷を，次に具体的な記述内容から確認してみよう。 先に見たように, 1970年頃までは「科学」への憧れが強く, 客観重視の立場が強か った。例えば, 客観重視の立場は,「できうる限り客観的普遍的な方式を守って,い かなる条件が加えられたときに，このような行動の変容が得られたかを克明に記録 する」（村上 1956，4-5頁 (T04-b)）ことを目指していた。村上（1956）はこのよ うなあり方を「科学的」であるといい, 同時に「科学的」を「実験条件の透明であ ることと, 検証可能であることと, この二つをかねそえたものである」としている (村上 1956, 4 頁 $[\mathrm{T} 04-\mathrm{b}]$ )。しかし, 臨床心理学においてはどうしても主観重視 の立場にならざるを得ないことが多い。だが, 当然のことながらそこでは「主観的 接近を, 個々の臨床心理学者の主観的な体験にとどめず, 臨床心理学者一般につら なる公共的な体験たらしめようとする努力」が要求される（村上 $1968 ， 8$ 頁 (T10 -b))。つまり, 客観的に対象を観察するのではないやり方で, いかにして個別的経 験から何らかの普遍性を獲得するに至るのか, という問題が主観重視の立場には残 るのである。「科学」であろうとする限り,この問題の解决は何らかの形で果たさね ばならないと心理臨床家は考えた。

そこで登場する解決法が，主客分離型解決と主客融合型解决である。まず，1970 年代以前によく見られた主客分離型の解決法の記述から見ていこう。

(インタビュー（クライエントとの面接）に客観性を持たせるためには)，イン タビューの記録そのものを，一定の手続きにしたがって客観的に分析していく ことを真剣に考慮せねばならない。インタビューを規定している条件があまり にも複雑なものである以上,これらの諸条件を統制することは至難であり, し たがって客観性を別のところ,すなわち分析の仕方にもとめる以外にはないだ ろう。(中略) インタビューは, 人間と人間とのふれあいにもとづくものであ り, 単なる技術に終わるものではないからこそ, われわれは科学的で客観的な 分析法を確立しておかなくてはならない。さもなければ, 臨床心理学そのもの が, 独断とひとりよがりのものとなり，科学ではなくなってしまう恐れがある。 (片口 1958，267頁 (T05-c) )

さらに,この解決は, できるだけ客観的に, クライエントとの主観的な相互作用 一つまり「事例」の記録・分析を行おうとするため, 「可能な範囲で, 多くの出所 
から情報を手に入れ, 事例史にふやしておくことは, 未だ若い科学である臨床心理 学の現状からみて, 特に大切な努力」（細野 1968, 298頁〔T10-f)）と考えるので ある。この引用中の表現からもわかるように，この解決は， Bの主観重視の立場を 比較的「科学」に近い形で解决しようとする方法であるといえる。

そしてこれと対照的なのが，1970年以降に多く登場し始める主客融合型解決であ る。このような解決はやや理解するのが難しい。一体いかにして，そのような主観 と客観の同時的成立がありえるのだろうか。代表的な説明は以下のようなものであ る。河合（1991〔T41-g]）は主にユング (C. G. Jung) の普遍的無意識 (collective unconscious）という概念を用いて, 個人の追求からいかにして普遍にいたることが 可能かを説明している。普遍的無意識というのは，個人的な無意識のさらに「哚い 層」にある,「広くは人類に共通」(264頁) の無意識である。「その心的内容は個人 差がなくなり, 万人に共通の様相を示す」(264頁)。例えば, 夢などで「自分の個人 史とは何ら関係がないが, その内容に関しては世界の神話や昔話, 宗教書などに述 べられていることと, 著しい類似性を示すものがある」（264頁）が，これには普遍 的無意識が関係していると考えられる。そして,「ユングはそのような普遍的無意識 の層を，客観的な心と呼んでいる」(265頁）という。そこから河合 (1991 [T41-g]) は以下のような見解にいたる。

客観的な心に生じていることでも，それは意識によって把握されているので， それを「主観」と呼ぶならば，主観と客観の一致とも考えることができる。（中 略）つまり，主観・客観は思いのほかに一致していて，簡単に分けられないと も思えてくるのである。(266頁)

この見解を言い直すならば，以下のように整理できる。つまり，個人の心の中に ある普遍的無意識は, 個人の意識で把握しうる主観でありながら, 一定の客観性を 備えているため, 主観と客観は明確には分離できない。ゆえに,「個から普遍に至る」 (河合 1995，24頁 (T44-b)）ことが可能になるのである。

\section{5.学校における「柔らかい事実」の志向}

以上の分析により，科学性に関する行為の倫理的規準 (以下，科学性規準と略す) が客観重視の立場から主客融合型解決の立場へと移行してきたことが明らかになっ た。科学性規準のこの変化は, 学校における臨床心理士の職域の拡大と大いに関連 
していたとみなせるが，それがもつ戦略上の意味を理解するには, 科学人類学者で ある Latour の議論が役立つだろう。Latour (訳書 1999)は，主張から自明の事実 を構成していく際の戦略を一般化したが, この一般化は, 臨床心理士の戦略を検討 する際にも応用できる。

Latour（訳書 1999）によれば，何らかの主張を広めていこうとする時，我々は 予め 1 つのパラドックスを抱えている。それは,「主張を広めるためには行為に参加 する人の数を「増やさ」なければならないが，同時に，主張を「そのままで」広め るためには行為に参加する人の数を「隇らさ」なければならない」（354頁）という ことである。

客観を重視する立場は，このパラドックスへの一方の対処法と言える。Latour \& Woolgar（1986）によれば，客観とは「（実験室においては）実験室の中の記録器や 実験室の外の研究者による論文から得られた幾つかのドキュメントを重ね合わせる ことによって完成されて」(84頁)いるものである。したがって，客観を重視する立 場では, 多くのリソースが結びついた客観的な主張を「そのままで」一例えば, 機械のようにパッケージングした形で一一広める努力がなされる。Latour（訳書 1999）は，このような努力を「固い事実を作る」と呼んだ。

これに対して主客融合型解決の立場は，少ないリソースしか動員されていない主 観的な主張を許容する。少ないリソースで組み立てられた主張を，Latour（訳書 1999）は「柔らかい事実」と呼ぶ。柔らかい事実を作ることは，パラドックスのも う一方の対処法であり,この場合，「そのままで」という部分を犠牲にして, 主張を 広めることが優先される。つまり, 主張に関連づけられているリソースの数を減ら し，人々が都合に応じて解釈し直せる部分を主張の中に残しておくことにより，参 加する人数を滅らす必要なく，主張を広めていくことが可能になるのである。

科学性規準を主客融合型解決とすることで, 臨床心理士は柔らかい事実を志向す るようになったが, それは, 次の 2 点で, 学校での職域拡大に適合的であったと考 えられる。第 1 に, 個々の臨床心理士が個人の自由裁量で扱える範囲を広げた点で ある。柔らかい事実への志向は，学問的に規定された専門職としての自由裁量では なく，あくまでも個人としての自由裁量で扱える範囲を広げる。現在行われている スクールカウンセリングは, 場所や時間の構造が非常にゆるやかである。臨床心理 学が1970年以前と同じように客観重視の立場でいた場合, これほどまで環境設定が ばらばらであると，専門家の仕事として容認するのが難しかっただろう。しかし， 柔らかい事実を志向するかぎり，このような状況でもまったく構わない。例えば, 
臨床心理士は個人の主観的な好みで持ってきた本でもカウンセリングに利用するこ とが許される。その本が場に固有の意味をもつのはもちろん, 主客融合型解決の考 え方により，それは客観的・普遍的にみても意味のあるものになりうるからである。 カウンセリング条件の統制が難しくなりがちな学校現場において, 多様な技術・道 具・環境等の許容がなければ, スクールカウンセラー事業の進展は非常に難しいも のになっていたはずである。

第 2 は, 臨床心理士の科学性規準が, 学校におけるほほ唯一の専門職である教師 の志向と親和的であったと考えられる点である。スクールカウンセラーの制度化の 際に，教師と臨床心理士の間で職務管轄争いが先鋭化することはほとんどなかった。 この事実は, 教師が臨床心理士と同じく柔らかい事実を志向する科学性規準をもち あわせていることを示唆している。Latour（訳書 1999）によれば，柔らかい事実 は他の主張（事実）と衝突しない。主張は, 伝えられると同時に参加する人々の手 によって変換されるため, 主張間の対立構造が明確化しないのである。そのため, そのような場では, 職務管轄をめぐる激しい競合も, 明確な分業も起こりえない。 それぞれの主張は，曖昧に共存する。しかし，そもそも場を同じくするのは，規準 が同じだからこそ可能なのである。この点は, 病院と比較するとわかりやすい。病 院には, 既に, 医学という固い事実を志向する学問体系が強固に存在する。そして, その体系に従い様々な専門職が既に位置づけられている。そこに, 臨床心理士が柔 らかい事実を志向したまま入り込むことは難しい。本稿の冒頭で述べているとおり， 病院での臨床心理士の資格をめぐる制度的な保証は非常に難航している。多様な専 門職間の対立がある病院というフィールドにおいては, 柔らかい事実の曖昧さはな かなか全面的には許容しえないのである。

以上, 教科書の分析から抽出された主客融合型解決という科学性規準が, 柔らか い事実を志向するという特徵に注目し，それが, 臨床心理士の職域拡大をめぐる現 状とどのように関連しているかを検討した。そこから, 通常, 専門職の職域確保に 役立つとは考えられない柔らかい事実を志向するという特性が, 学校という特殊な フィールドにおいては有効に働いているのではないかと推論された。もちろん現時 点でそれは仮説に過ぎないが，臨床心理士の職域拡大およびそれを受け入れる学校 という場の特異性を捉え直すさいに，心理主義化という社会趨勢だけでなく，知そ のものに注目することが一定の意義をもつということは確かである。 
〈注〉

（1）日本臨床心理士資格認定協会は文部科学省認可の財団法人で，1982年設立の日 本心理臨床学会が中心となって立ち上げた組織である。1988年から臨床心理士の 資格認定を開始した。臨床心理士の有資格者は，原則として，医師会を模した臨 床心理士会に所属することになっている。あまり一般には知られていないが，い わゆる「心の専門家」に関係する資格には様々なものがあり，それらを一括りに 扱うことは混乱を招く。本稿では, 現在最も活動が活発な資格である臨床心理士 にのみ，焦点を当てることにする。

（2）現在，スクールカウンセラーは原則として，臨床心理士・精神科医・大学教員 のいずれかであることとされているが(村山 2002)，ここでは，経過措置として 採用が認められている「スクールカウンセラーに準ずる者」114名も含んだ。

（3）臨床心理士は最近認定を開始した一資格であるため，1988年以前は存在しなか った。そのためここでは臨床心理学を学び臨床に携わる者を総称してこのような 表現を使っている。原則として, 臨床心理士のみをさす場合はその呼称を用いる が，文脈上明確に区別できない場合は心理臨床家と呼称する。心理臨床家には臨 床心理士も含まれるが,ここでの力点はあくまでも，臨床心理士および1988年以 降臨床心理士になっていく心理臨床家にある。

（4）ここでは, 専門職をある「問題」を再定義し, 解決を行うための知の体系を有 している職業と広義に捉えることとする。英米の医師・弁護士など典型的な専門 職に限定した，狭義の定義についての議論は，進藤（1990）を参照のこと。

(5) 職域の拡大や資格の制度化は, もちろん, 直接的には政治的過程の結果である。 臨床心理士の文部省への接近, およびその前提となった臨床心理学の学会の確 立・資格認定業務の開始といった政治的活動を考慮することは欠かせない（この ような過程については保田 [2001]を参照)。しかし，政治的活動は表面的な現象 に過ぎない。その活動を下支えしている個々の臨床心理士の行為規準を明らかに することが, より重要かつ現状を理解するために有効であると考えた。

(6) Kuhn の議論はあくまでも自然科学についてのものであるが, 臨床心理学の教 科書の記述内容を見る限り, 同様と見なせる点は多いと思われる。例えば, 臨床 心理学の教科書内で抽象的な言葉と共に示されている事例は, 何が臨床心理学的 であり何が臨床心理学的でないかを判断するための「見本例」として機能してい ると考えられる。また，もちろん，教科書の記述はあくまでも規範的なレベルの ものであるが，ここでは倫理的規準の指標とするので問題はない。 
（7） 2000年代については，1 シリーズしか把握できていなかったので，それをその まま採用した。しかし，所蔵館件数が十分に多く，影響力のある教科書であるこ とは間違いない。

（8）ただ，臨床心理士が一つの資格として広く注目されていくにつれ，客観性重視 の立場（A）も見直されつつあるようである。大量の臨床心理士の水準確保のた めには，現在医療分野で盛んに言われている Evidence-based medicine のような 実践形態が有効だからである。実際,この EBM 運動の発想に基づき書かれた坂野 氏の別著書（坂野雄二編 2000 , 「臨床心理学キーワード」有斐閣）は, 臨床心理 士になるために大学院受験を目指す人々の間では, そのわかりやすさゆえ, 広く 受け入れられている。

\section{〈文献〉}

Abbott, Andrew 1988, The System of Professions, The University of Chicago Press.

伊藤茂樹 1996,「「心の問題」としてのいじめ問題」「教育社会学研究」第59集, 2137頁。

加野芳正 2001, 「不登校問題の社会学に向けて」『教育社会学研究』第68集, 5-23 頁。

Krippendorff, Klaus 1980, Content Analysis: an introduction to its methodology, Sage Publications, (=1989, 三上俊治・椎野信雄・橋元良明訳『メッセージ 分析の技法——「容分析」への招待」勁草書房).

Kuhn, Thomas S. 1962, The Structure of Scientific Revolutions, University of Chicago Press, (=1971, 中山茂訳「科学革命の構造』みすず書房).

Latour, Bruno \& Woolgar, Steve 1986, Laboratory Life: The Construction of Scientific Facts 2nd ed., Princeton University Press.

Latour, Bruno 1987, Science in Action: How to follow science and engineers through society, Harvard University Press, (=1999, 川崎勝・高田紀代志 訳「科学が作られているとき」産業図書).

Merton, Robert K. 1957, Social Theory and Social Structure: Toward the Codification of Theory and Research (revised), The Free Press, (=1961, 森東吾・森好夫・金沢実・中島竜太郎訳『社会理論と社会構造』みすず書房). 森真一 1999,「心理学のへゲモニー一一社会のフレキシブルな編成と心理主義化」 
『ソシオロジ』第44巻 2 号, $37-53$ 頁。

村山正治 2002,「学校臨床心理業務の社会的意義」村山正治・鶇養美昭編「実践！

スクールカウンセリング』金剛出版, 23-35頁。

日本臨床心理士会 2002 , 「平成13年度厚生科学研究「臨床心理技術者の資格のあり

方に関する研究」報告書に対する意見書(詳細)」, http://webclub.kcom.ne. $\mathrm{jp} / \mathrm{ma} / \mathrm{jsccp} /$ oshirase/sikakuhokoku/shosai.pdf。

進藤雄三 1990, 『医療の社会学』世界思想社。

鈴木二郎 2002, 「平成 13 年度厚生科学研究「精神疾患治療ガイドラインの策定に関 する研究』「臨床心理技術者の資格のあり方に関する研究」平成11-13年度・ 分担報告書」, http://webclub.kcom.ne.jp/ma/jsccp/oshirase/sikakuhokoku/sikakuhoukoku.pdf。

Svensson, Lennart G. 1990, "Knowledge as the professional resource: case studies of architects and psychologists at work," R. Torstendahl \& M. Burrage eds., The Formation of Professions: Knowledge, State and Strategy, Sage Publications, pp. 51-70.

Torstendahl, Rolf 1990, "Introduction: promotion and strategies of knowledgebased groups," R. Torstendahl \& M. Burrage eds., The Formation of Professions: Knowledge, State and Strategy, Sage Publications, pp. 1-10.

保田直美 2001,「戦後日本における学校への臨床心理学的知の導入過程」「大阪大 学教育学年報』第 6 号, 13-24頁。 


\title{
ABSTRACT
}

\section{The Change of Scientific Principles in Clinical Psychology}

\author{
YASUDA, Naomi \\ (Graduate School, Osaka University) \\ 1-2 Yamadaoka, Suita, Osaka, 567-0871 Japan \\ Email: yamaoka@ hus. osaka-u. ac.jp
}

Recently, Japanese schools are increasingly employing clinical psychologists as school counselors. This increase is generally understood as reflecting a characteristic trend of present society that emphasizes psychological reasoning in everyday life. On the other hand, however, clinical psychologists have not been accepted in hospitals as successfully as in schools. The purpose of this paper is to search for the key factor behind the increase in clinical psychologists in changes of clinical psychology itself, especially its "knowledge" and "scientific principles."

Forty-five textbooks published in post-war Japan were analyzed. It was found that a remarkable change of scientific principles in clinical psychology occurred in the 1970s. Most of the textbooks published before 1970 emphasized the importance of objectivity. However, therapists could not completely exclude subjectivity from their practices because of the face-to-face relationship with their clients. This dilemma was resolved through the introduction of a new perspective in clinical psychology, which simultaneously emphasizes both subjectivity and objectivity. Clinical psychologists applying this perspective believed that therapists could reach universal objectivity through subjectivity. After the 1970s, this belief came to prevail in clinical psychology and to support the practice of therapists.

Generally speaking, the change of principles has led clinical psychologists to construct more "soft facts," which Latour, the French anthropologist of science, defined as facts with less resources for persuasion. This transformation to "soft facts" from "hard facts" may be a contributing factor to the increase of clinical psychologists in schools. First, by constructing "soft facts" instead of "hard facts," clinical psychologists became able to conduct counseling at school without strictly controlling the conditions for it. Second, by emphasis "soft facts" rather than "hard facts," the practice of therapists becomes more easily approved by schoolteachers, who have the same orientation. From this point, some differences between schools and hospitals are considered. 